دور المرأة الريفية فى التنمية الززاعية والاقتصادية المستدامة فى محافظة القليوبية

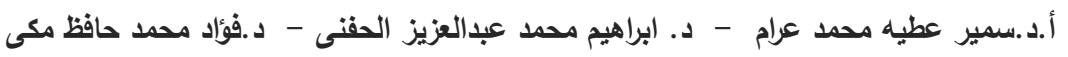

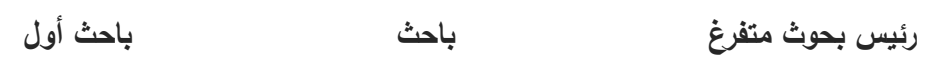

معهة بحوث الاقتصاد الززاعى - مركز البحوث الزراعية

Corresponding author: Alhfny7500@gmail.com

اهتصت الدولة بوجه عام والقيادة السياسية بوجه خاص خلال السنوات الأخيرة خاصة بعد عام 2014 بقضايا المرأة بهدف الاستفادة القصوى

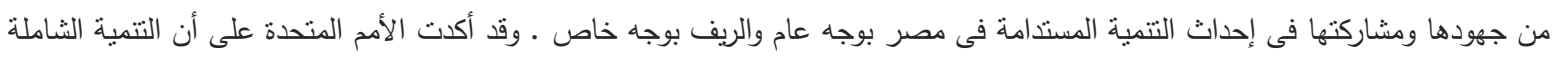

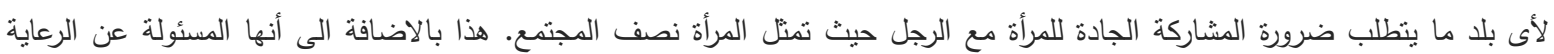

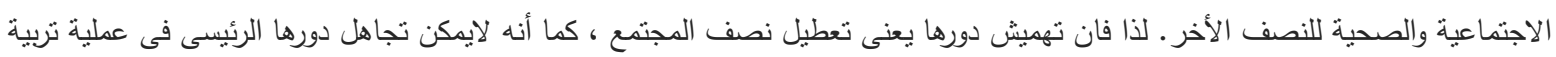
الابناء والذى ينعكس أثره على المجتمع ككل. وقد بدء الأهتمام من قبل الدولة بالمرأة منذ عام 1988 حيث ثم انثاء المجلس القومى للطفولة والأمومة. والمشاركة فى الاتفاقية الدولية

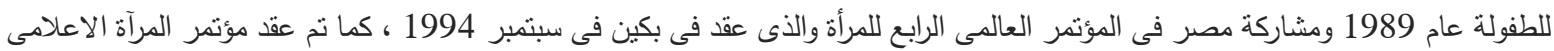
فى مايو 2000. وتحرص الدولة الأن على اصدار القوانين والقرارات التى تجعل المرأة شريك قوى فى التتمية الاقتصادية والسياسية للاولة ككل وذلك من خلال دستور 2014 الذى اعطى للمرأة الحق فى عضوية البرلمان بكوته محددة حوالى 25\% لضمان عدم انخفاض نسبة مشاركتهم السياسية ، ثم بعد ذلك تم ادخالهم الى منصب الوزير فى الوزارات المختلفة ولكونهم قد ثبتوا تفوقهم بل حصلت وزيرة التخطيط والاستثمار تفوقها العالمى التى فحصلت على أفضل وزيرة فى هذا الدجال عام 2020 على مستوى الدول العربية ، كما نم اختيار الدكتورة غادة والى وزيرة التضامن السابقة لمنصب مرموق بالامم المتحدة بالاضافة الى النجاحات التى تحققها المرأة فى هذا المنصب الرفيع كوزارة الصحة وقوة مشاركتها فى مواجهة فيروس الصناف كورونا ووزيرة الصناعة والتجارة التى شاركت فى توسع الدولة فى المشروعات الصغيرة على مسنتى الجمهوريه بوجه عام والريف المصرى بوجه خاص ، كما تم تعيينها فى مجال القضاء وقد زاد اهمام الدوله في السنوات الاخيره بالمراه الريفيه باصدار القرارات التي تحد من زواج القاصرات ومنح المرأه المعيله المساعدات والقروض التي تحتاجها لتيسير حياتها المعيشيه

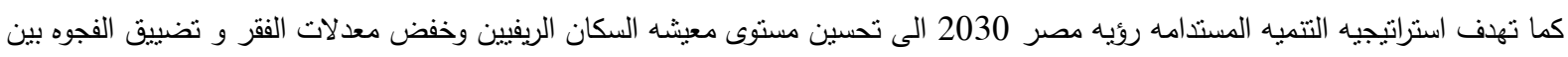
الجنسين وتتميه الموارد البشريه و توفير فرص عمل منتجه في الزراعه والانشطه المرتبطه بها وتفعيل دور المراه في مختلف الانشطه الريفيه وتحقيق

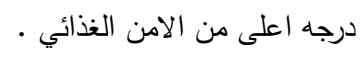

\title{
مشكله الاراسة
}

تتتثل مشكلة الدراسة في انه على الرغم من اهتمام الدولة المتزايد خلال السنوات الاخيره لدمج المراه في المجتمع من خلال مشاركتها مشاركه جاده في التتميه المستدامه باصدار القوانين والقرارات المدعمه لها سواء على مستوى مصر كلها بوجه عام او الريف بوجه خاص الا ان مشاركتها الجاده مازالت لا تتاسب مع كونها تمنل نصف المجتمع ومسؤليتها عن الرعايه الاجتماعبه للنصف الاخر وقد يرجع ذلك الى العديد من العادات

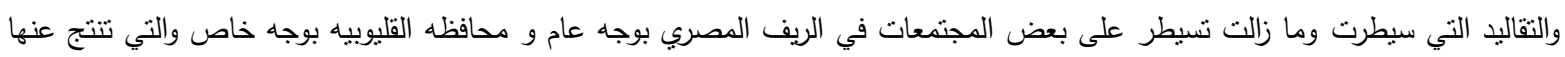
ارتفاع نسبه الاميه بين النساء وانعكاسها سلبيا على تربيه ابنائهن وعلى سلوكهم الانجابي فادي ذلك الى زياده السكان زياده عشوائيه غير مدروسه ينتج عنها انتثار الفقر بين معظم سكان الريف فأثز ذلك سلبيا على مقومات التتميه الزراعيه والاقتصاديه بالريف المصري كله ومما زاد من الآثار

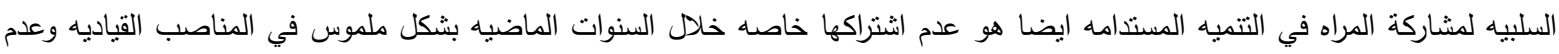

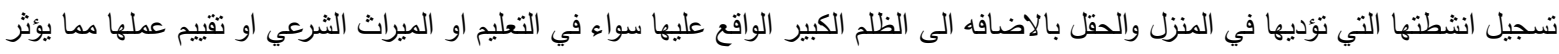

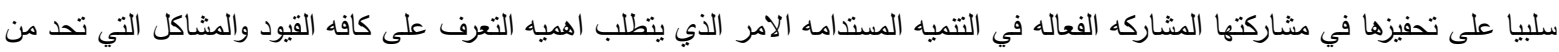

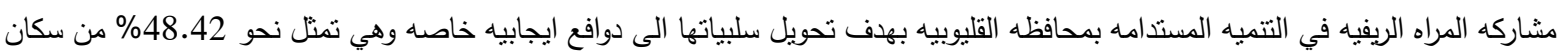


تهدف الدراسه بشكل اساسي الىى التعرف على دور المراه الريفيه في التتميه الزراعيه والاقتصاديه المستدامه بريف محافظه القليوبيه واهم العوامل المؤثره عليها سلبيا وذللك من خلال مجموعه من الاهداف الفرعيه والمتمتله فى الاتى 1- الخصائص الاجتماعيه والاقتصاديه لمجتمع الدراسه 2- - التعرف على ما تمتلكه افراد العينه من أصول خدميه وانتاجيه 3- التعرف على دور المرأه في العوامل الديمجرافيه والصحيه لأ فراد اسرتها واثر ذلك على التتمبه المستدامه. 4- اثر المستوى التعليمي للمراه الريفيه على أهم المتغيرات المؤثره على التتميه المستدامه لدهاه

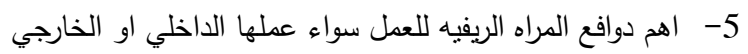
6- مؤشرات كفاءه الاداء الاقتصادي لأهم الانشطه التي تمارسها المبحوثة بعينة الدراسه 7- اهم المشاكل التي تحد من مشاركه المراه في التتميه المستدامه بمراكز وقرى العينيه 8- اهم العوامل التي تحد من مشاكل عدم مشاركه المراه في التنميه المستدامه بعينه الدراسه

اهميه الدراسه :- ترجع اهميه الدراسه الى امكانيه التعرف على اهم العوامل التي تحد من المشاركه الفعليه للمراه الريفيه في التتميه المستدامه و مدى امكانيه الحد من تأثيرها السلبي على مقومات التنميه ومد صانع القرار بالنتائج التي يمكن الوصول اليها من خلال الدراسه الميدانيه مع غيرها

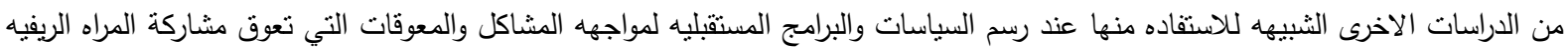
مشاركه جاده في تحقيق التتميه المستدامه في الريف المصري خاصده وان الدوله مقبله على بداية تتميه الريف وتطويره هذا العام 2021 الطريقه البحثيه و مصادر البيانات:اولا: الطريقه البحثيه استخدمت الدراسه في تحقيق الهدف منها اسلوبى التحليل الوصفي والكمى المناسبين للبيانات التي يتم الحصول عليها من

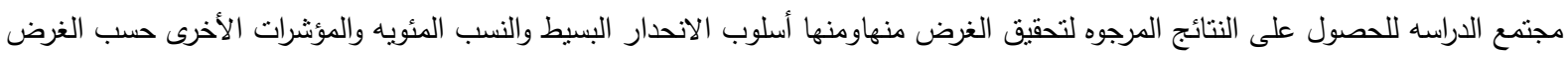
من الدراسه. ثانيا : مصادر البيانات :اعتمدت الدراسه على نوعين من البيانات حيث تمنل الاول منها فى البيانات الثانويه المنشوره وغير منشوره من مديريه الزراعه بالقليوبيه ومركز

المعلومات بالمحافظه والجهاز المركزي للتعبئه العامه والاحصاء ومجلس المراه بالاضافه الى الدراسات وثيقه الصله بموضوع البحث الحالى لئى

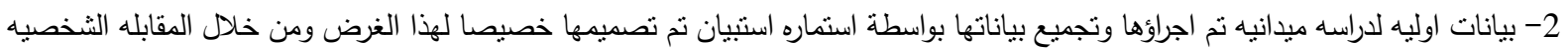
للمبحوثين وعددهم (80 اسره) من سكان الريف بمحافظه القليوبية عينه الاراسه الميدانيه :- وقع الاختيار على مركز قليوب حسب عند عددان السكان حيث بلغ نحو 740ألف نسمه ومركزالخانكه بلغ نحو 680 ألف بلف نسمه يمتل عدد سكان الريف بالمركز الاول حوالى 79\% بينما يمثل المركز الثاني نحو 88.12\% من اجمالي عدد السكان بكل مركز وبلغت نسبة الأناث

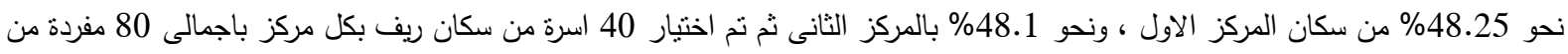

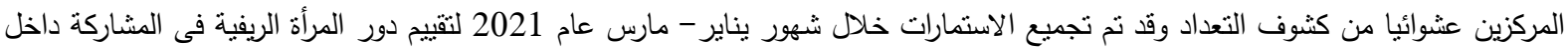
الأسرة فى التتمية المستدامة التي تسعى الدوله لتحقيقها خلال السنوات الاخيره.

$$
\text { نتائج البحث :- }
$$

اولا : الأهمية النسبية لعدد السكان بمحافظة القليويية مقارنة بالجمهورية : يثير جدول (1) الى نطور عدد السكان فى مصر ومحافظة القليوبية خلال الفترة (2008 - 2019) وتبين الاتى : بالئه : 1- بلغ منوسط اجمالى عدد سكان الجمهورية خلال فترة الدراسة حوالى 86.4 مليون نسمة بحد أدنى بلغ نحو 75.2 مليون نسمة عام 2008 بنسبة انخفاض عن المتوسط العام بلغت نحو 13\% نقريبا، بينما بلغ الحد الاقصى حوالى 98.9 مليون عام 2019 بنسبة ارتفاع بلغت نحو 14.5\% من المتوسط العام بعدد سكان الجمهورية . 2- بلغ متوسط اجمالى عدد السكان بمحافظة القليوبية حوالى 5.05 مليون نسمة بحد أدنى بلغ نحو 4.4 مليون نسمة عام 2008 بنسبة انخفاض بلغت نحو 12.9\% عن المتوسط العام، فى حين بلغ الحد الاقصى عام 2019 حيث بلغ عدد السكان حوالى 5.8 مليون نسمة بزيادة بلغت نحو 14.8\% عن المتوسط العام. 
ويؤكد ذلك تحليل الاتجاه الزمنى العام بالجدول رقم (2) حيث تثير المعادلة رقم (1) الى أن عدد سكان الجمهورية يزيد بمعدل سنوى قدر

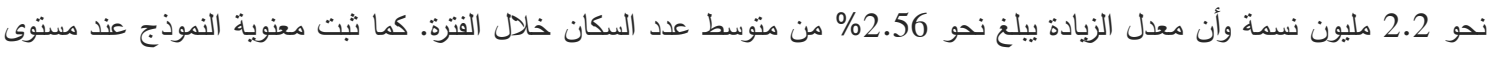

كما يشير الجدول فى المعادلة رقم (2) الى أن عدد سكان محافظة القليوبية بزيد بمقدار حوالى

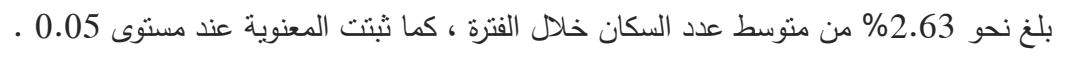
3- تثير دلائل تقدير عدد سكان مصر بالداخل فى يناير 2021 من خلال الجهاز المركزى بحوالى 101 مليون نسمة تمثل نسبة الذكور

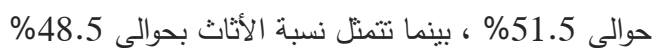

4. تثير دلاثل تقدير عدد سكان محافظة القليوبية خلال منتصف عام 2020 حسب بيانات الجهاز المركزى للتعبئه العامه والاحصاء الى حوالى

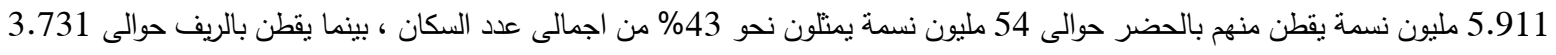

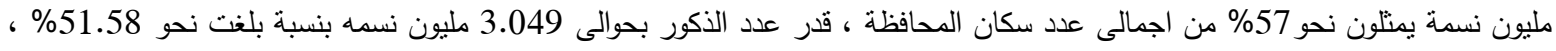

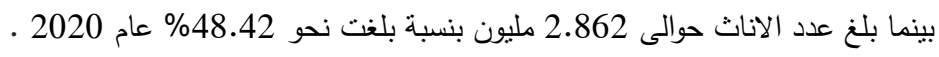
جدول رقم (1) نظور عدد السكان فى مصر ومحافظة القليوبية خلال الفترة (2008 - 2019) بالالف نسمة

\begin{tabular}{|c|c|c|c|}
\hline$\%$ & القليوبية & الجمهورية & السنوات \\
\hline 5.84 & 4395 & 75194 & 2008 \\
\hline 5.84 & 4493 & 76925 & 2009 \\
\hline 5.84 & 4595 & 78685 & 2010 \\
\hline 5.83 & 4699 & 80530 & 2011 \\
\hline 5.83 & 4812 & 82550 & 2012 \\
\hline 5.82 & 4926 & 84629 & 2013 \\
\hline 5.81 & 5044 & 86814 & 2014 \\
\hline 5.79 & 5156 & 88958 & 2015 \\
\hline 5.72 & 5215 & 91086 & 2016 \\
\hline 5.91 & 5627 & 95203 & 2017 \\
\hline 5.91 & 5747 & 97147 & 2018 \\
\hline 5.90 & 5832 & 98900 & 2019 \\
\hline 6.09 & 5045 & 86385 & المتوسط \\
\hline
\end{tabular}

المصدر : جمعت من الجهاز المركزى للتعبئة العامة والاحصاء ، الكتاب الاحصائى السنوى، اعداد مختلفة . - - محافظة القليوبية ، مركز المعلومات ودعم اتخاذ القرار .

- - 2. - جدول رقم (2) معادلات الاتجاه الزمنى العام لعدد السكان فى مصر ومحافظة القليوبية خلال الفترة (2008 - 2019)

\begin{tabular}{|c|c|c|c|c|c|}
\hline التغير السنوى معدل & العنوسط & $F$ & $\mathrm{R}^{2}$ & المعادلة & r \\
\hline 2.56 & 86385 & 1243.7 & 0.99 & $\begin{array}{r}Y^{\wedge}=72008.3+221108 X_{t} \\
(35.7)^{*}\end{array}$ & 1 \\
\hline 2.63 & 5045 & 319.2 & 0.96 & $\begin{array}{r}Y^{\wedge}=4180.37+133.03 X_{t} \\
(17.85)^{*}\end{array}$ & 2 \\
\hline
\end{tabular}


ثانيا : نتائج الدراسه الميدانيه :

1- الخصائص الاجتماعية والاقتصادية لأسر المبحوثين بعينة الدراسة الميدانية :

يشير جدول (3) الى أهم الخصائص الاجتماعية والاقتصادية لأسر المبحوثين بعينة الدراسة الميدانية بمراكز محافظة القليوبية خلال موسم 2020/ 2021

أ- رب الاسرة بعينة الدراسة:وهو المسئول الاول عن رعاية الأسرة والانفاق عليها، حيث اتضح أن عدد الازواج من الرجال والذين هم على قيد الحياة ييلغ عددهم بمركز قليوب نحو 22 رجل يمثلون نحو 55\% ، بينما بلغ عددهم بالمركز الثانى الخانكة نحو 24 رجل بنسبة بلغت نحو 60\% من فرة اجمالى عدد

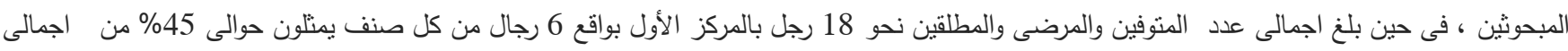
العينة ، بينما يمنل كل صنف من الاصناف الثناثة حوالى 15\% ، بينما بلغ اجمالى عدد المتوفين، والمرضى، والمطلقين بالمركز الثانى حوالى 16 رجل بمنلون

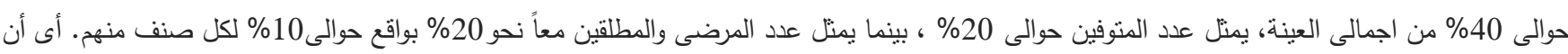
العينة تفقد دخل نحو 45\% من الرجال بالمركز الأول، وحوالى 40\% بالمركز الثانى مما يشير الى أهمية خروج المرأة للعمل لتدبير نفقات ومنطلبات أفراد أسرتها بالقدر المناسب.

ب- - عدد أفراد الأسرة :بلغ اجمالى عدد أفراد أسر المبحوثين نحو 204 فرد بالمركز الأول بمتوسط بلغ حوالى 5.1 فرد للأسرة الواحدة يمثل

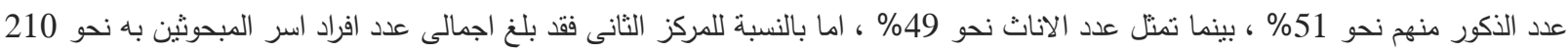

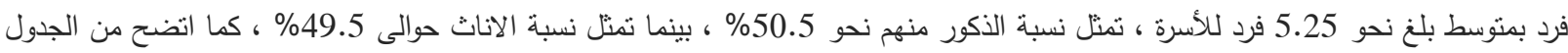
أن نسبة الأطفال دون سن المدرسة بلغ نحو 39.2\% من اجمالى عدد أفراد أسر المبحوثين بالمركز الأول ، بينما تمثل نسبة من هم فى سن التعليم

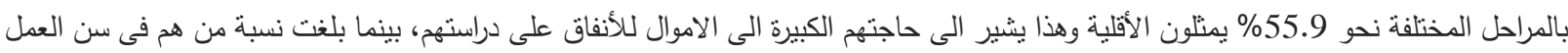

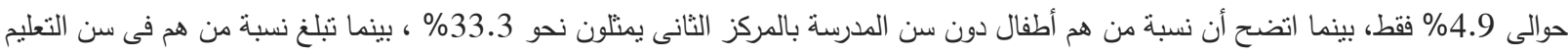

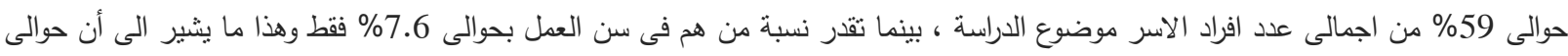

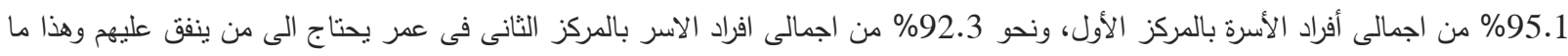

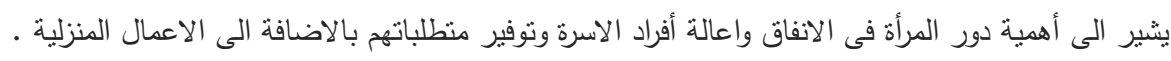

2أ- المستوى التعليمي لرب الاسره

انحصر المستوى التعليمى لرب الاسره من حد ادنى بلغ 14.4\% من التعليم الجامعى وحد اقصى بلغ نحو 42.8\% لمستوى يقرأ ويكتب

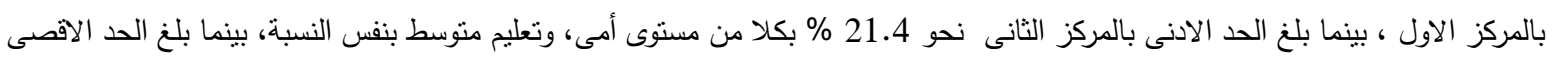

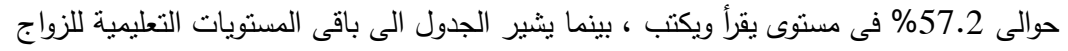

ب- المستوى التعليمي للزوجه

انحصر مستواها التعليمى ما بين حد ادني بلغ نحو 20\% نعليم منوسط وحد اقصي مبلغ نحو 45\% في المستوى الامي بالمركز الاول

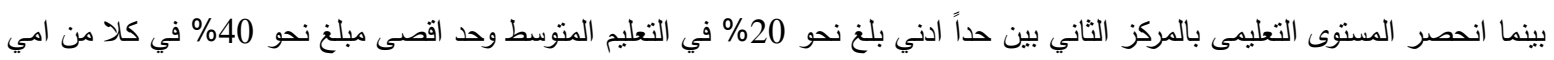
و يقرأ وبشير الجدول الى باقى المستويات التعليميه للزوجه .

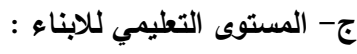

انحصر المستوى التعليمي للابناء ما بين حد ادني بلغ نحو 2.6\% في المستوى الجامعي وحد اقصى نحو 51.6\% في سن سن الحضانه بالمركز الاول بينما بلغ الحد الادنى بالمركز الثاني نحو 3.8\% فى المستوى الجامعي،وحد أقصى بلغ نحو 45.5\% فئى سن الحضانه بينما رصد بالجدول

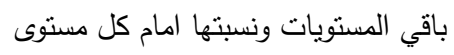

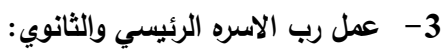
يوضح الجدول أن عدد الأزواج من منهم على قيد الحياة وبعد استبعاد المتوفين والمطلقين بلغ عددهم حوالى 28 فرد فى كل من المركز الاول

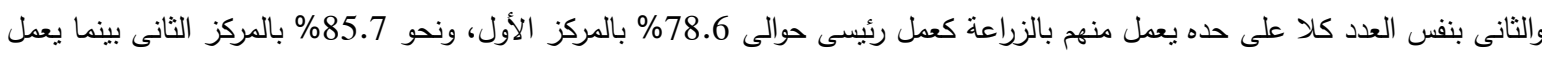
نحو 21.4\% بالمركز

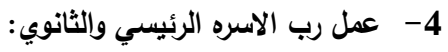
يوضح الجدول أن عدد الأزواج من منهم على قيد الحياة وبعد استبعاد المتوفين والمطلقين بلغ عددهم حوالى 28 فرد فى كل من المركز الاول والثانى بنفس العدد كلا على حده يعمل منهم بالزراعة كعمل رئيسى حوالى 78.6\% بالمركز الأول، ونحو 85.7\% بأع بالمركز الثانى بينما يعمل نحو 21.4\% بالمركز الاول ، ونحو 14.3\% بالمركز الثانى عمل ثانوى بجانب العمل الرئيسى كالعمل لاى الغير أو بمشاريع خاصة 
5- - 5 - 5 الاخل من عمل رب الاسره

بلغ متوسط الدخل من العمل الرئيسى لرب الاسره حوالي 1000 جنيه بالمركز الاول و 1500 بالئن 1500 جنيه بالمركز الثاني بينما بلغ الدخل الثانوي نحو

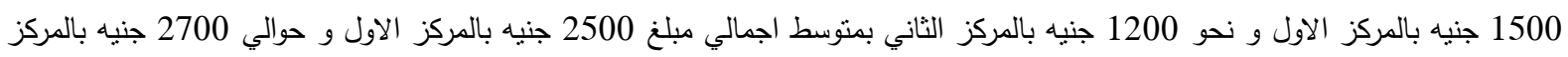

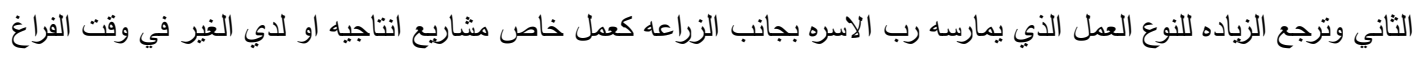

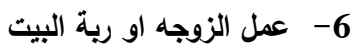

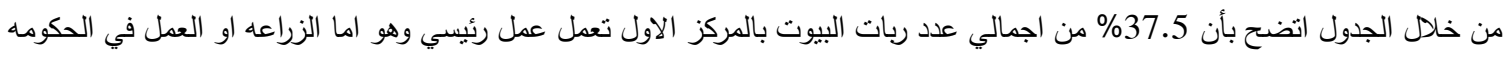

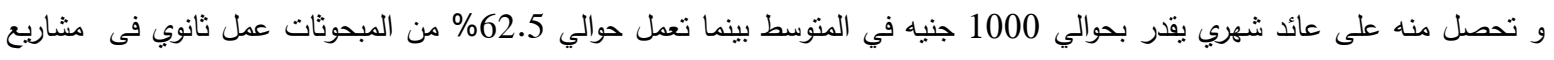

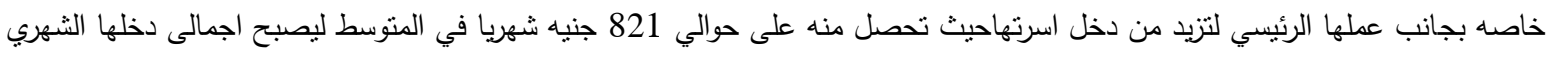

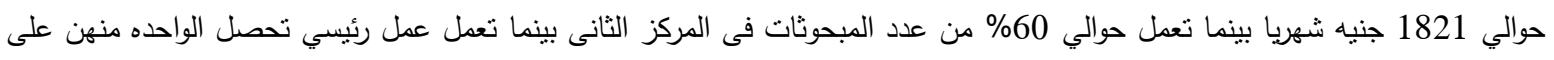

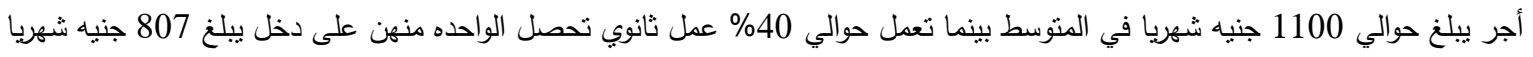

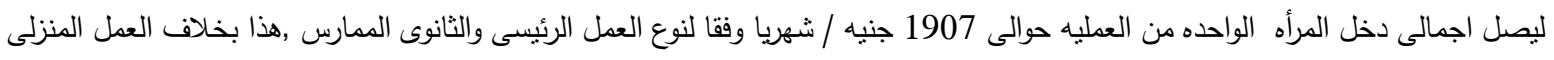

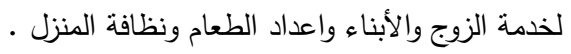

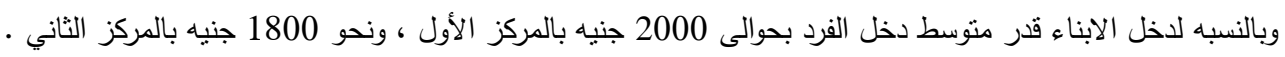

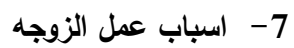

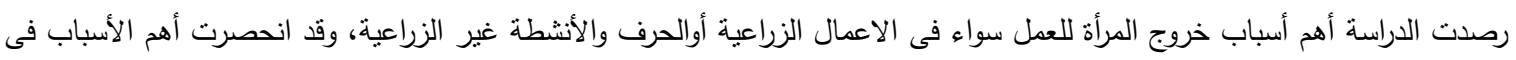

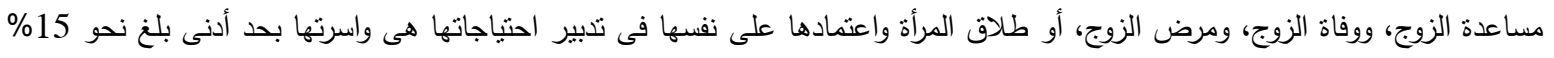

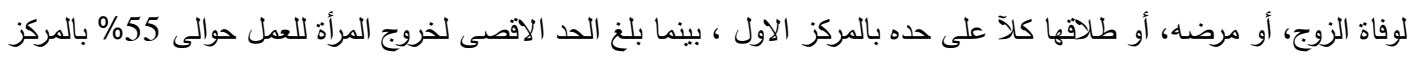

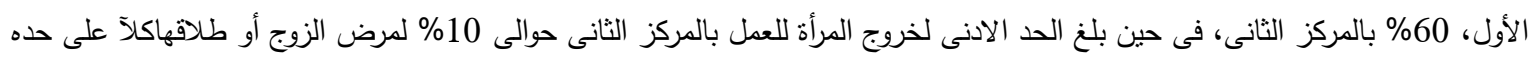

\section{- - ما ما تثارك به المرأة من دخلها فى الانفاق على الاسرة :}

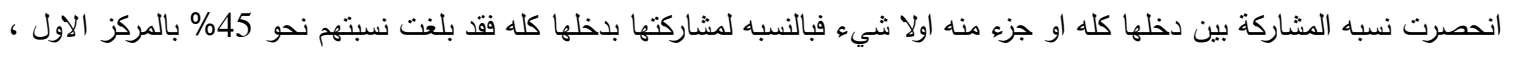

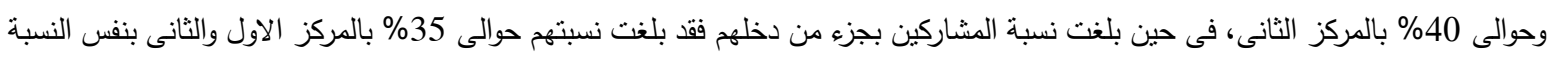

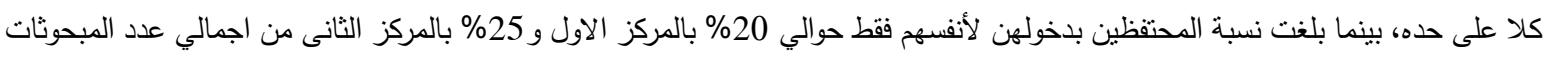

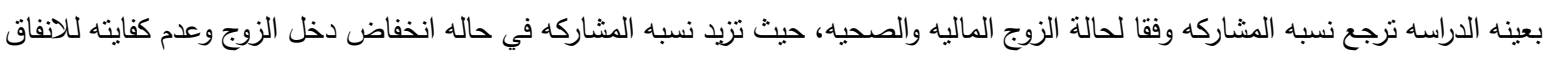

على الاسره او مرضه او وفاته او طلاقها وخروجها للعمل لسد حاجه اسرتها (المراه المعيله)

3- صافى العائد الثهرى من أهم الأنثطة التى تمارسها المرأة الريفية كما جاء بعينة الدراسة :

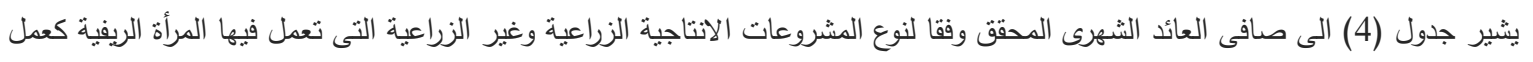

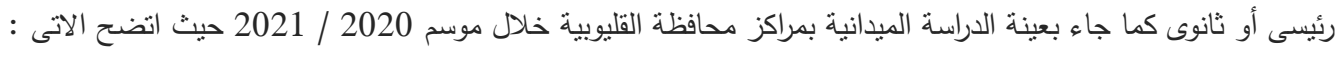

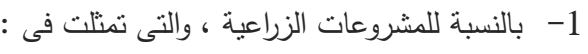

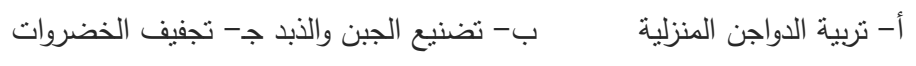

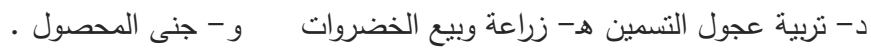

وتحقق المرأة صافى عائد من ممارسة هذه الانثطة بقدر متوسطة بحوالى رئع 1000 جنيه بالمركز الأول 


\begin{tabular}{|c|c|c|c|c|c|c|c|c|c|c|c|c|}
\hline \multicolumn{2}{|c|}{ المركز الثانى } & \multicolumn{2}{|c|}{ المركز الاول } & \multirow{2}{*}{\multicolumn{2}{|c|}{ البيان }} & \multicolumn{2}{|c|}{ المركز الثانى } & \multicolumn{2}{|c|}{ المركز الاول } & \multicolumn{3}{|c|}{ البيان } \\
\hline$\%$ & عدد & $\%$ & عدد & & & $\%$ & عدد & $\%$ & عدد & & & \\
\hline 85.7 & 24 & 78.6 & 22 & رئيسى & عمل رب & 60 & 24 & 55 & 22 & \multicolumn{2}{|c|}{ على قيد الحياة } & \\
\hline 14.3 & 4 & 21.4 & 6 & ثانوى & الاسرة & 20 & 8 & 15 & 6 & فقى & & 了. \\
\hline \multirow[t]{5}{*}{100} & 28 & 100 & 28 & الاجمالى & (يعمل) & 10 & 4 & 15 & 6 & & & $\overline{3}$ \\
\hline & 1500 & & 1000 & رئيسى & الاخل من & 10 & 4 & 15 & 6 & لق & & 3 \\
\hline & 1200 & & 1500 & ثانوى & عل رب & 100 & 40 & 100 & 40 & & & \\
\hline & 2700 & & 2500 & الاجمالى & الاسرة & 50.5 & 106 & 51 & 104 & ور & & \\
\hline & & & & & (جنيه) & & & & & & & \\
\hline 60 & 24 & 37.5 & 15 & رئيسى & عمل & 49.5 & 104 & 49 & 100 & ث & & q⿻ \\
\hline 40 & 16 & 62.5 & 25 & ثناتوى & الزوجة & 100 & 210 & 100 & 204 & مالى & & :ब, \\
\hline \multirow[t]{4}{*}{100} & 40 & 100 & 40 & الاجمالى & (تعمل) & 33.4 & 70 & 36.2 & 80 & المدرسة & ق ق قبل سرز & $\frac{1}{1}$ \\
\hline & 1100 & & 1000 & رئيسى & الاخل من & 59.0 & 124 & 55.9 & 114 & عليم & & $\overline{3}$ \\
\hline & 807 & & 821 & ثانوى & عمل & 7.6 & 16 & 4.9 & 10 & بون & & .5 \\
\hline & 1907 & & 1821 & الاجمالى & (الزوجية) & & 210 & & 204 & مالّى & & \\
\hline 100 & 16 & 100 & 10 & رئيسى & عمل & 21.4 & 6 & 21.4 & 6 & أم & \multirow{4}{*}{$\frac{3}{30}$} & \multirow{16}{*}{ 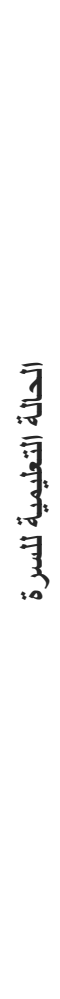 } \\
\hline- & - & - & - & ثانوى & الابناء & 57.2 & 16 & 42.8 & 12 & & & \\
\hline 100 & 16 & 100 & 10 & الاجمالى & (يعملون) & 21.4 & 6 & 21.4 & 6 & تمتوسيم & & \\
\hline- & 1800 & - & 2000 & رئيسى & منعمل & - & - & 14.4 & 4 & تعلىيم & & \\
\hline- & - & - & - & ثانوى & الابناء & 100 & 28 & 100 & 28 & & & \\
\hline- & 1800 & - & 2000 & الاجمالى & (جنيه) & 40 & 16 & 45 & 18 & & & \\
\hline 60 & 24 & 55 & 22 & مساعدة & اسباب & 40 & 16 & 35 & 14 & تقرأ & & \\
\hline 20 & 8 & 15 & 6 & الزفاة & الزوجة عمل & 20 & 8 & 20 & 8 & متوسط تعتب & 高 & \\
\hline 10 & 4 & 15 & 6 & مرض الزوج & & - & - & - & - & تعليم & & \\
\hline 10 & 4 & 15 & 6 & طلأق & & 100 & 40 & 100 & 40 & & & \\
\hline 100 & 40 & 100 & 40 & الاجمالى & & 45.5 & 70 & 51.9 & 80 & حضانة & & \\
\hline 40 & 16 & 45 & 18 & كله & ما تشارك & 19.5 & 30 & 19.5 & 30 & ابتدائى & & \\
\hline 35 & 14 & 35 & 14 & جزء منه & به الزوجة & 23.4 & 36 & 19.5 & 30 & اعدادى & & \\
\hline 25 & 10 & 20 & 8 & لا شئ & من دخلها & 7.8 & 12 & 6.5 & 10 & ثانوى & . & \\
\hline \multirow[t]{2}{*}{100} & 40 & 100 & 40 & الاجمالى & فى حالة & 3.8 & 6 & 2.6 & 4 & جامعة & - & \\
\hline & & & & & الزوج & 100 & 154 & 100 & 154 & الاجمالى & & \\
\hline
\end{tabular}

المصدر: جمعت وحسبت من بيانات الدراسة الميدانية بمراكز محافظة القليوبية خلال الفترة من يناير - مارس 2021 . و 1100 بالمركز الثانى شهرباً.

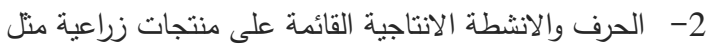
أ- تضيع الخبز الفلاحى ب-تضيع المخبوزات والفطائروتحقق صافى عائد مبلغ متوسطه 800 جنيه بالمركز الاول ,700 جنيه بالمركز الثانى

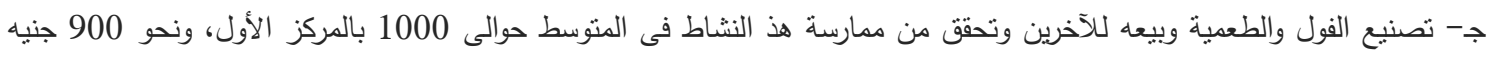
بالمركز الثانى كعائد صافى/شهريا . 3- المشروعات والحرف الغير زراعية وتتمنل هذه المشروعات فيى : أ- الخياطة وتدر دخل يبلغ صافيه حوالى 800 جنيه بالمركز الأول ، 900 جنيه بالمركز الثانى . التطريز والسرفله وتعطى هذه الحرفة صافى دخل يبلغ منوسطة حوالى 750 جنيه بالمركز الأول ، ونحو 800 جنيه

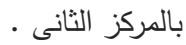
ج- محلات لبيع البقالة والمواد الغذائية وييلغ منوسط صافى عائدها الثهرى 1000 جنيه بالمركز الاول ، 1100 بالمركز الثانى . 
د- محلات لبيع الأدوات المنزلية ويبلغ منوسط العائد الثهرى منها 800 جنيه بالمركز الأول، وحوالى 700 جنيه بالمركز الثانى . هـ- مصوغات حرفية وقد قدر صافى العائد الثهرى منها حوالى 600 جنيه بالمركز الأول، ونحو 550 جنيه ، بالمركز الثانى وهذه

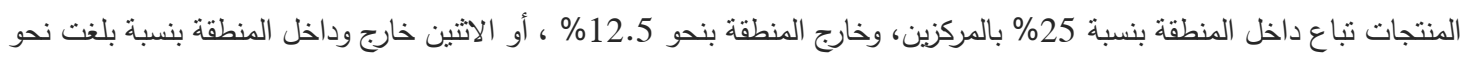

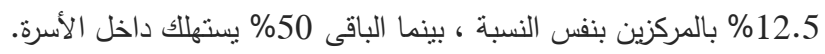

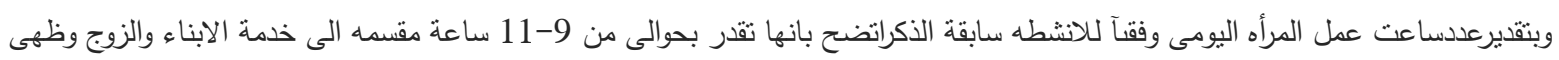

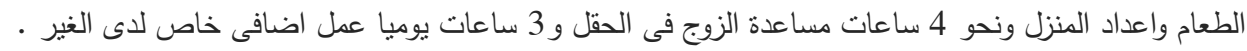

4- الحيازة المزرعية والأصول الخدمية المملوكة للمبحوثين بعينة الدراسة :

يشير جدول (5) الحيازة المزرعية والحيوانية والأصول الخدمية المملوكة للمبحوثين بعينة الدراسة بمراكز محافظة القليوبية موسم 2020 / 2021

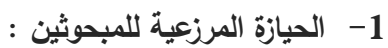

وتتضمن كلا من الاراضى الملك والايجار باجمالى مساحة بلغت نحو 80 فدان بالمركز الاول ، وحوالى 75 فدان بالمركز الثانى منهم

ملك حوالى 68.5 فدان بالمركز الاول وحوالى 63.5 فدان بالمركز الثانى والباقى 11.5 فدان ايجار بكل مركز .

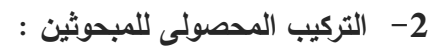

أ- العروة الصيفية ويزرع بها الذرة ، والارز، الفول السودانى، وقصب السكر بالمركز الاول ، بحد أدنى بلغ حوالى 10 فدان مزروعة

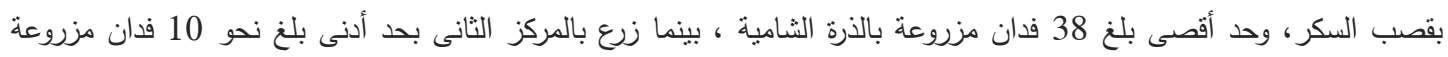

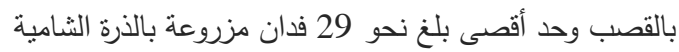

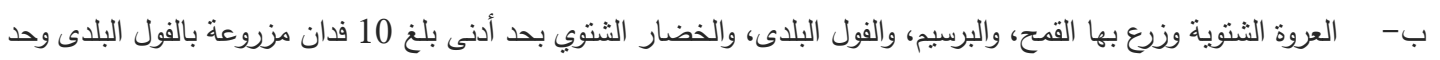

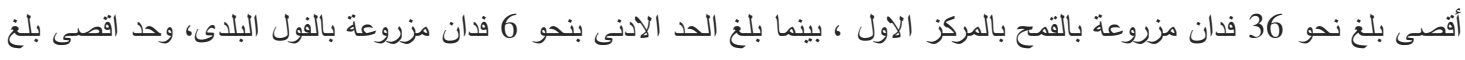
حوالى 35 فدان مزروعة بالقمح بالمركز الثانى.

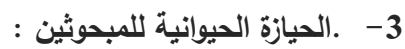

وتمثلت فى الابقار والجاموس والجمال والدواب باجمالى بلغ حوالى 104رأس بالمركز الألى الأول، ونحو 115رأس بالمركز الثانى ، كما

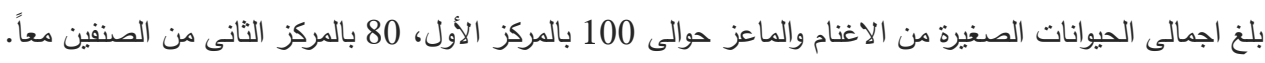

4- الأصول الخدمية المنزلية :

وتمثلت فى الثلاجات ، الفريزرات ، والتليفزيونات ، وأفران تعمل بالغاز والغسالات الاتوماتك والعادية، والراديو والتسجيل باجمالى

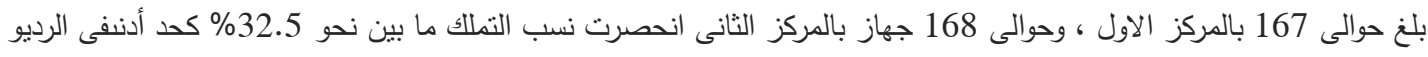

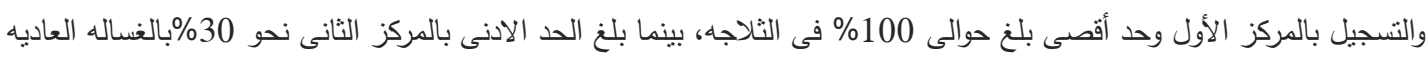
وحد أقصى بلغ نحو 100\%فى الثلاجات من تملك هذه الأجهزة والتى يختلف تملكها وفقا للحالة التعليمية والاقتصادية لكل أسرة . 5- 5 منزل المبحوثين وملحقاته :

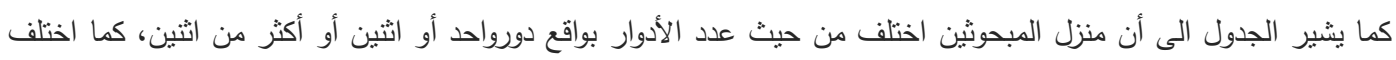
ايضا من حيث نوع طوب البناء (طوب أخضر ، أو احمر، أو حجر ابيض) حيث اتضح أن العدد الاكبر من البيوت مكون من دورين بنسبة 50\% بالمركز الاول ،نحو 60\% بالمركز الثانى، كما اتضح ايضا أن النسبة الاكبر من المنازل مبنية بالطوب الأحمر بنسبة

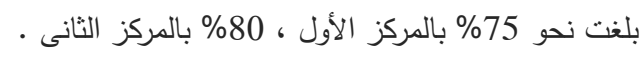
موقع حظائر تربية المواشى : جاءت النسبة الأكبر من عدد الحظائر موجودة داخل المنزل بنسبة بلغت نحو

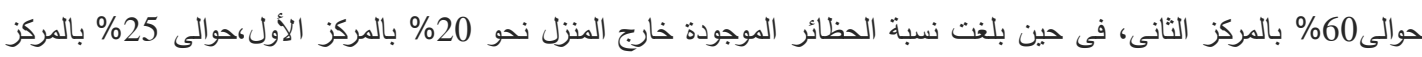

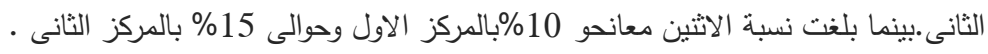

جدول 4. صافى العائد الشهرى المحقق وفقا لنوع المشروعات الانتاجية الزراعية وغير الزراعية التى تعمل فيها المرأة الريفية كعمل رئيسى أو

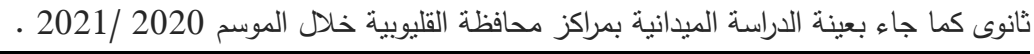

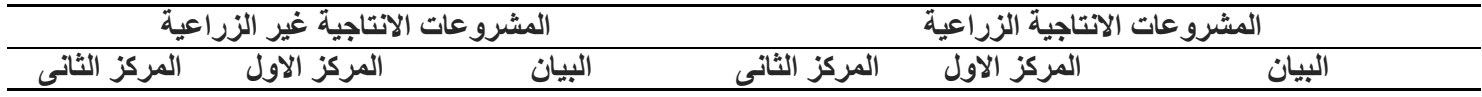




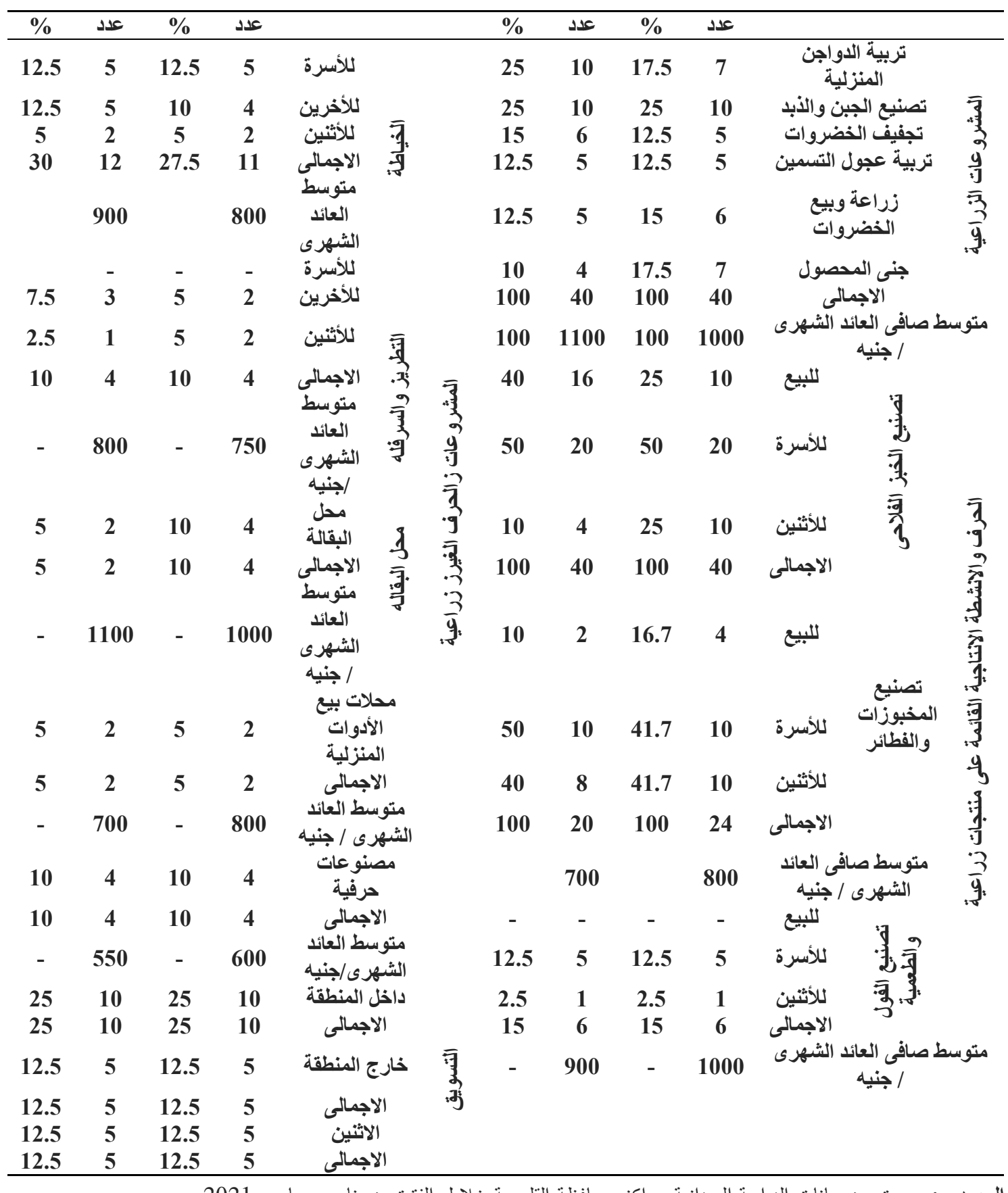

المصدر : جمعت من بيانات الدراسة الميدانية بمراكز محافظة القليوبية خلا ل الفترة من يناير - مارس 2021 .

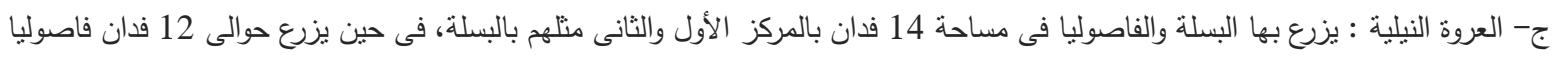
بالمركز الأول ونحو 14 فدان بالمركز الثانى باجمالى 26، 28 فدان بكل مركز على حده

خامسا المشاركه في الحياه السياسيه والسلوك الاجتماعي للمراه بعينة الدراسة: يشير جدول (6) المشاركة في الحياة السياسية والسلوك الاجتماعى للمرأة بمراكز عينة الدراسة الميدانية بمحافظة القليوبية خلال 2020/ 2021

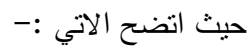
- مشاركه المراه في الحياه السياسيه :- 
تثتير بيانات الجدول الى ان هناك تقدم ملحوظ في دور المراه في المشاركه السياسيه في السنوات الاخيره مقارنه بما قبل 2014 نظرا

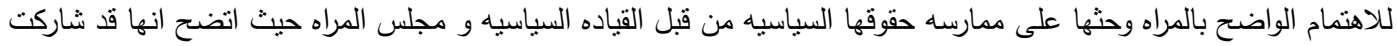

في :-

أ- اختيار رئيس الجمهوريه بنسبه بلغت نحو 75\% بالمركز الاول، 60\% بالمركز الثاني من عدد المبحوثين . جدول رقم 5. الحيازة المزرعية والحيوانية والأصول الخدمية المملوكة للمبحوثين بعينة الدراسة الميدانية بمراكز محافظة القليوبية موسم 2020

2021/

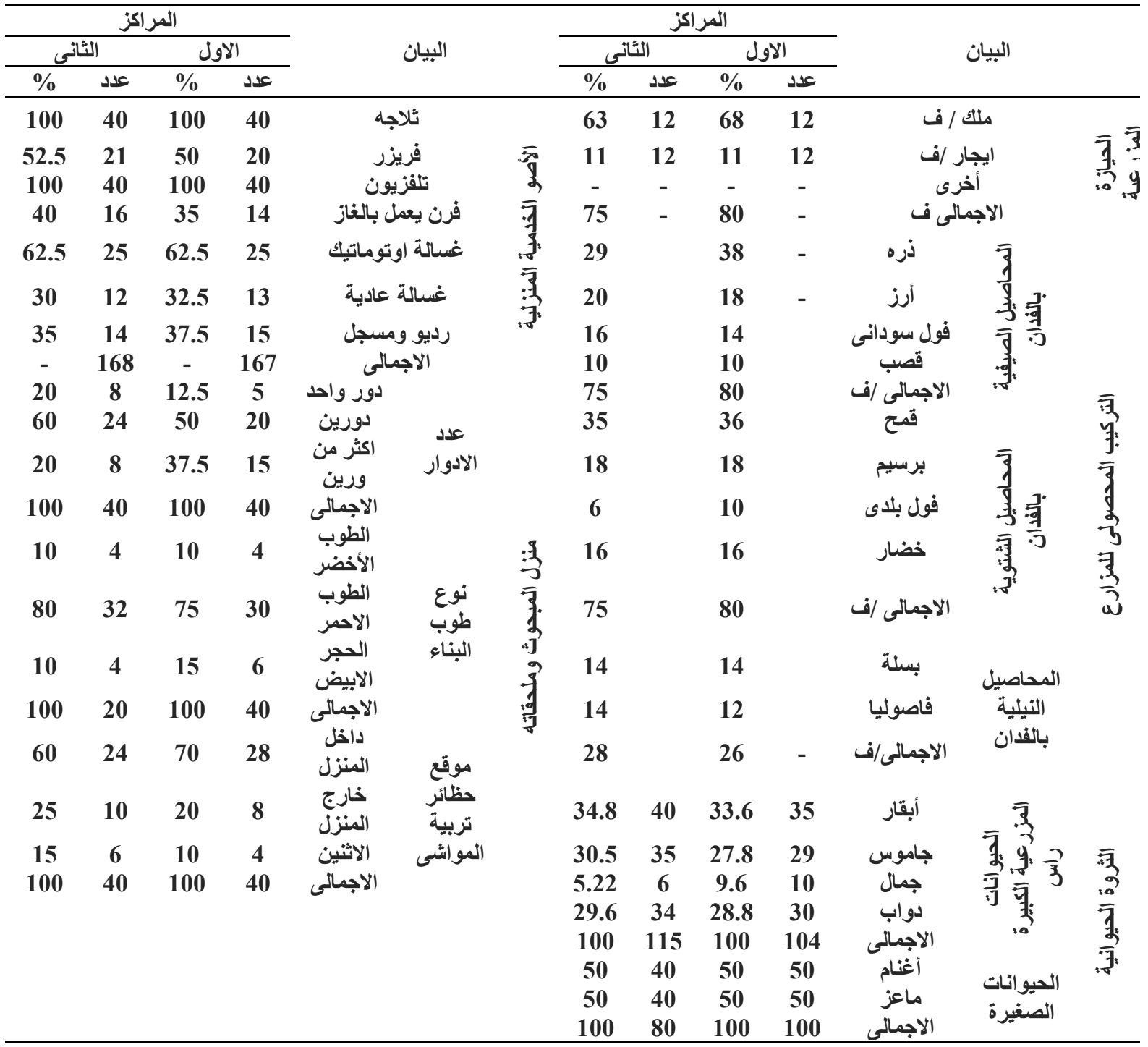

المصدر : جمعت وحسبث من بيانات الدراسة الميدانية بمراكز محافظة القليوبية خلال الفترة من يناير - مارس 2021 .

ب- مجلس الثيوخ وقد شاركت المرأة في انتخاباته الأخيرة 2020 بنسبة بلغت نحو 25\% ، بالمركز الأول ، وحوالى 20\% مركز الثاني من

اجمالي عدد المبحوثين.

ج- مجلس النواب الاخير في 2020 شاركت المراه بنسبه بلغت نحو 40\% بالمركز الاول و حوالي 45 بالمركز الثاني.

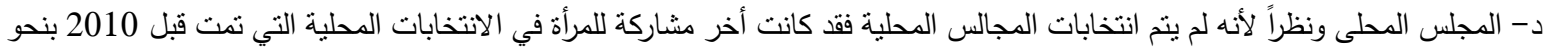

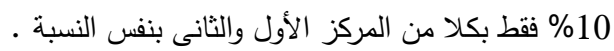

هـ - الجمعيات الزراعبه وقد شاركت المراه ايضا فيه اخر النخابات للجمعيات الزراعيه قبل 2010 بنسبه بلغت حوالي 15\% بالئ بالمركز الاول

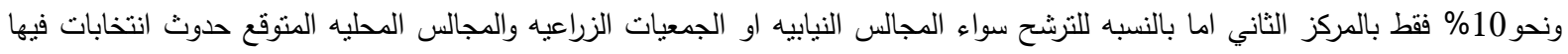

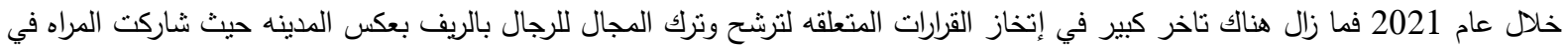

الانتخابات النيابيه سواء الدوره الجديده او في الدوره المنتهيه مع الرجال. 
و - حضور الندوات التثقيفيه

نجد بأن هناك مشاركة من قبل الريفيات في حضور منل نلك الندوات بنسبة بلغت نحو 25\% بالمركز الأول، وحوالى 20\% بالمركز الثاني من اجمالي عدد المبحوثات بعينه الدراسه.

2

أ-سن الزواج مازال هنالك بالريف حدوث زيجات في سن أقل بكثير من السن القانونى مع التحايل بأساليب منوارثة، حيث بلغت نسبة المتزوجات في عمر أقل من 18 سنة حوالى 40\% بالمركز الاول ، وحوالى 35\% بالمركز الثاني ،بينما بلغت نسبة المتزوجات عن عمر ما بين (20 - 35 سنة) بنسبة بلغت نحو 45\% بالمركزين بنفس النسبه كلا على حده .

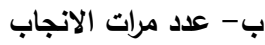

انحصرت عدد مرات الانجاب ما بين حد أدنى بلغ مرة واحدة بنسبة بلغت نحو 5\% بالمركز الأول ،وحوالى 10\% بالى بالمركز الثانى، بينما بلغ الحد الاقصى لعدد مرات الولادة 3 مرات بنسبة بلغت نحو 35\% بالمركز الأول ، ونحو 40\% بالمركز الثاني من اجمالي عدد المبحوثات

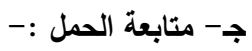

بلغت نسبة المبحوثات المنابعات للحمل بمراكز العينة نحو 75\% بالمركز الأول، ونحو 85\% بالمركز الثانى، فى حين بلغت نسبة غير المتابعات للحمل حوالى 25\% بالمركز الاول، وحوالى 15\% بالمركز الثانى.

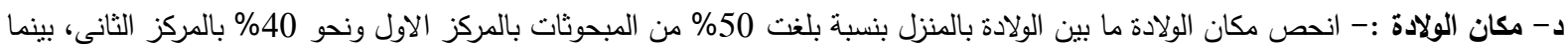

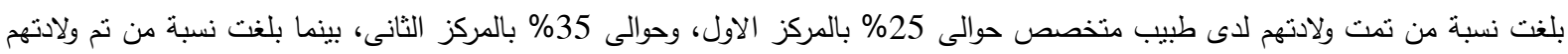

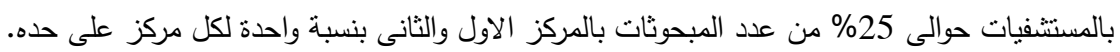

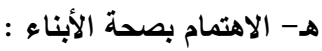

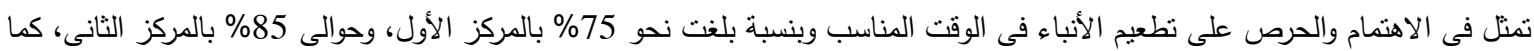

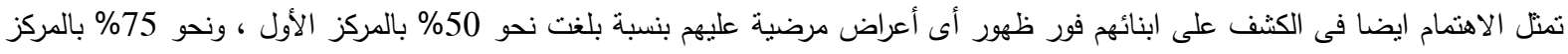

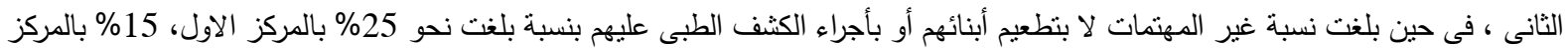

الثانى • وذلك من اجمالى عدد المبحوثات.

سادسا اهم المشاكل المتعلقه بمنطقه السكن والاقامه التي تحد من تاديه المراه الريفيه لدورها في التنميه المستدامه: يشير جدول (7) التكرار النسبي لاهم المشاكل المتعلقه بمنطقه السكن والاقامه التي تحد من تادية المراه الريفيه لدورها المنوط به في التنميه المستدامه كما رصدتها الدراسه الميدانيه بمراكز محافظه القليوبيه موسم 2020 / 2021 حيث اتضح بانها انحصرت في 12 مشكله على النحو التالي :-

1- قله الخدمات المقدمه لسكان المنطقه حيث اقر بها حوالى 7.8\% بالمركز الاول و 12\% بالمركز الثاني من اجمالي اراء المبحوثين.

2- قله عدد وسائل النقل والمواصلات المتاحة وجاءت بنسبة بلغت نحو 7.8 بالمركز الاول وحوالى 8\% بالمركز الثاني من اجمالي اراه

المبحوثين.

3- انقطاع الكهرباء لفترات طويلة بالمنطقة ، حيث أقر بذلك نحو 3.9\% بالمركز الاول ، وحوالى 4\% بالمركز الثانى من اجمالى الاراء

للمبحوثين.

4- عدم وجود مباه نقية ، حيث تفتقد معظم القرى للمباه النقبة حيث أقر بذلك نحو 7.8\% بالمركز الأول ، وحوالى 8\% من اجمالي اراء

المبحوثين بالمركز الثاني.

5- ارتفاع نسبة المخلفات وتمثل نسبة أراء المقربين بذلك بنحو 9.4\% بالمركز الاول ، وحوالى 8\% بالمركز الثاني من من اجمالي اراء

المبحوثين.

6- كثره العشوائيات بالمنطقه مما يفقدها الثكل الجمالي وتمثل نسبة المقرين بذلك بنحو 7.8\% بالمركز الاول ونحو 8\% بالمركز الثاني من

اجمالي اراء المبحوثين.

7- عدم وجود الصرف الصحى بكل القرية، وتمنل نسبة المقرين بهذه المشكلة بنحو 11.7\% بالمركز الاول ونحو 10\% بالمركز الثاني من

اجمالى اراء المبحوثين.

8- بعد الاسواق وعدم كفايتها لسكان المنطقه حيث بلغت نسبه اراء المقرين بذلك نحو 7.8\% بالمركز الاول، و حوالي 8\% بالمركز الثاني من

اجمالي اراء المبحوثين.

9- انخفاض اسعار بيع المنتجات المباعه بالمنطقه والتي تم انتاجها بقري العينه بنسبه بلغت نحو 7.8\% بالمركز الاول، ونحو 8\% باء بالمركز

الثاني من اجمالي اراء المبحوثين. 


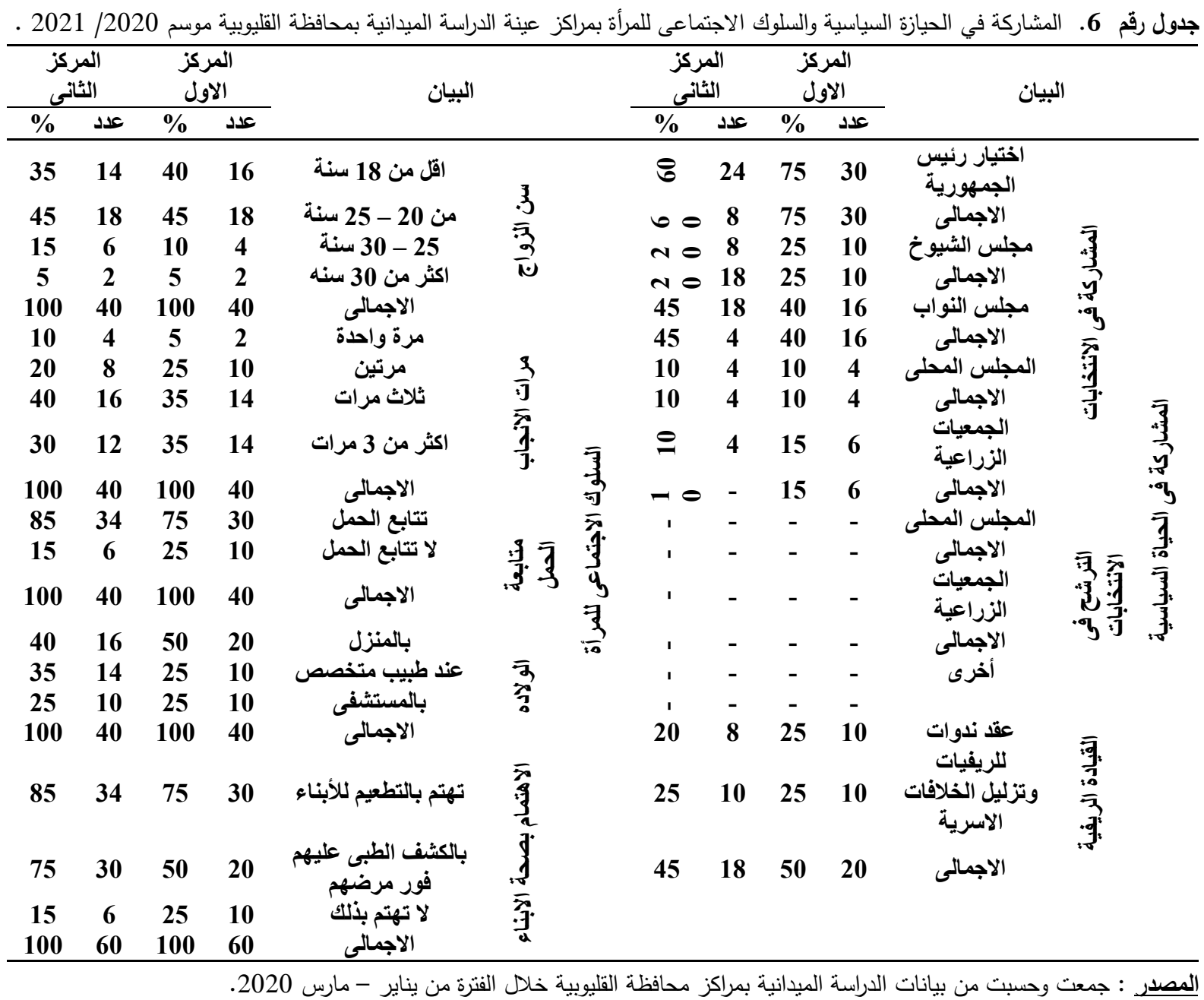

10- قله عدد المدارس بالمنطقه وهذا يشكل تكدس كبير للاطفال بالفصول مما يعوق العمليه التعليميه من جهه وانتشار الامراض من جهه اخرى حيث اقر بذلك حوالي 7.8\% بالمركز الاول ونحو 8\% بالمركز الثانى من اجمالي عدد المبحوثين.

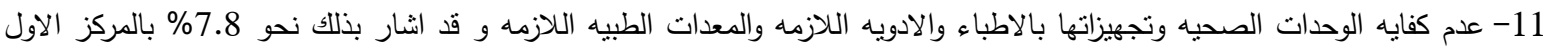
وحوالي 10\% بالمركز الثانى وذللك من اجمالي عدد المبحوثين. 12- كثرة التعدي على الاراضي الزراعيه ، حيث بلغت نسبه المقرين بذلك نحو 11.7\% بالمركز الاول ونحو 8\% بردي المركز الثاني ولهذا التعدي

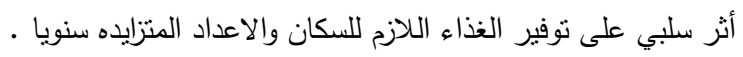

سابعا اهم المشاكل المتعلقه بسكان الريف انفسهم والتي تحد من تاديه دور المراه في التنميه يثنير جدول (8) النكرار النسبي لا هم المشاكل الخاصه بسكان الريف انفسهم والتي تحد من نادية المراه الريفيه لدورها في النتميه المستدامه

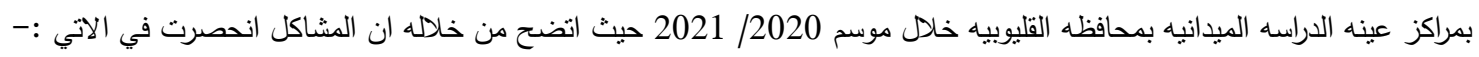
1- ارتفاع نسبه الاميه بين الاناث بنسبه بلغت نحو 11.2\% بالمركز الاول و حوالي 14\% بالمركز الثاني من اجمالي اراء المبحوثين

2- انخفاض الوعي الصحي نتيجه عدم الاهتمام بالتطعيم والكثف الطبي نتيجه انخفاض الدخول في الريف بنسبه بلغت 11.2\%

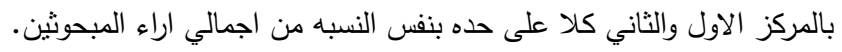
3- انخفاض الوعي الغذائي نتيجه لارتفاع نسبه الاميه من جهه وانخفاض الدخول من جهه اخرى مما يدفعهم الى عدم الاهتمام بالتغذيه

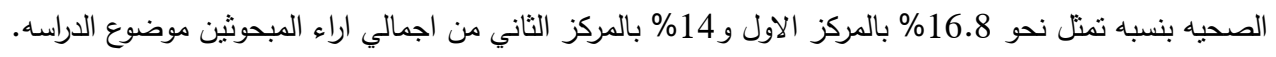


4- الاهتمام بتعليم الذكور فقط حيث تلجا بعض الاسر في الريف الى الاهتمام بتعليم الذكور دون الاناث على اساس ان الذكور هم رجال المستقبل ومصدر العمل وتحقيق الدخل المناسب بعكس الاناث و تمثل نسبه المقرين بذلك حوالي 5.6\% بكلا من المركز الاول والثاني بنفس النسبه كلاعلى حده من اجمالي الاراء للمبحوث

جدول رقم 7. التكرار النسبى لأهم المشاكل المتعلقه بمنطقة السكن والاقامه و التى تحد من تأدية المرأة الريفية لدورها المنوط به فى التتمية المستدامة، كما رصدتها الدراسة الميدانية بمراكز محافظة القليوبية عام 2020/ 2021

\begin{tabular}{|c|c|c|c|c|c|}
\hline \multicolumn{2}{|c|}{ المركز الثانى } & \multicolumn{2}{|c|}{ المركز الأول } & \multirow{2}{*}{ 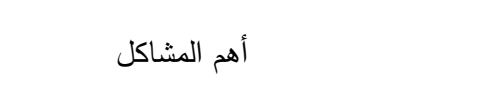 } & \\
\hline$\%$ & عدد & $\%$ & عدد & & \\
\hline 12 & 30 & 7.8 & 20 & 1- قلة الخدمات المقدمة لسكان المنطقة & \\
\hline 8 & 20 & 7.8 & 20 & 2- قلة عدد وسائل المواصلات المتاحة & \\
\hline 4 & 10 & 3.9 & 10 & 3- انقطاع الكهرباء لفترات طويلة & \\
\hline 8 & 20 & 7.8 & 20 & 4- عدم وجود مياه نقية & 急 \\
\hline 8 & 20 & 9.4 & 24 & 5- ارتفاع نسبة المخلفات & -1 \\
\hline 8 & 20 & 7.8 & 20 & 6- كثرة العشوائيات بالمنطقة & 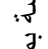 \\
\hline 10 & 25 & 11.7 & 30 & 7- عدم وجود الصرف الصحى بكل المنطقة & 曹 \\
\hline 8 & 20 & 7.8 & 20 & 8- بعد الأسواق وعدم كفايتها لسكان المنطقة & $\overline{3}$ \\
\hline 8 & 20 & 7.8 & 20 & 9- انخفاض أسعار بيع المنتجات المباعة & $\stackrel{5}{-1}$ \\
\hline 8 & 20 & 7.8 & 20 & 10- قلة عدد المدارس بالمنطقة & $\frac{19}{3}$ \\
\hline 10 & 25 & 7.8 & 20 & 11- عدم كفاية الوحدات الصحية وتجهيزها & \\
\hline 8 & 20 & 11.7 & 30 & 12- كثرة التعدى على الأراضى الزراعية & \\
\hline 100 & 250 & 100 & 254 & 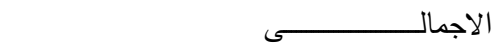 & \\
\hline
\end{tabular}

5- انخفاض الوعي البيئي نتيجه لكثرة مخلفات المزارع من جهه وصرف المراحيض ومخلفات الحظائر على المجاري المائيه من جهة أخرى ممايحدث التلوث بالماء والارض والهواء بنسبه بلغت حوالي 11.2\% بالمركز الاول والثاني بنفس النسبه كلا على حده من اجمالي اراء المبحوثين. 6- ارتفاع نسبه كثافه السكان بالمنطقه القربيه نتيجه الارتباط مليا والرغبه في التجاوز مع الأصدقاء والاقارب والحظر المعمول على البناء في الاراضي الزراعيه بنسبه بلغت 8.9\% بالمركز الاول ونحو 8.4\% بالمركز الثاني من اجمالي عدد اراء المبحوثين بعينه الدراسه.

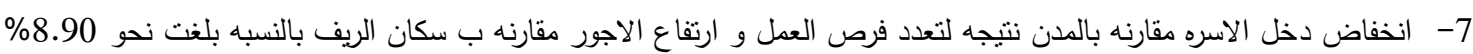
بالمركز الاول و حوالي 8.4\% بالمركز الثاني من اجمالي عدد اوراق المفحوصين بعينه الدراسه.

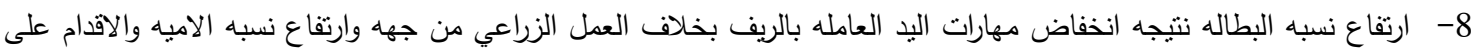
نوعيه التعليم منخفض الجوده بنسبه اراء بلغت نحو 11.2\% بالمركز الاول و 14\% بالمركز الثاني من اجمالي عدد المبحوثين. 9- الظلم الواقع على المراه في توزيع الميراث ويلجأ كثير من سكان الريف الى عدم اعطاء المراه حقها خاصه في الاراضي والاحتفاظ

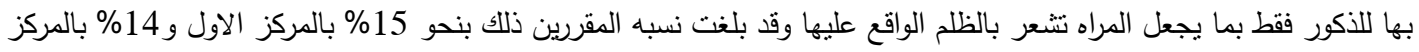
الثاني من اجمالي عدد اوراق المبحوثين بعينه الدراسه.

ثانيا:- اهم الاساليب المتبعه للحد من تاثير المشاكل سواء الخاصه بمنطقه السكن والاقامه او بالسكان انفسهم والتي تعيق تادية المراه للدورها في التنميه المستدامه يشير جدول (9) التكرار النسبي لأهم الاساليب المتبعه للحد من المشاكل التي تعيق المراه الريفيه من تأدية دورها في التتميه المستدامه بمراكز عينه الدراسه الميدانيه بمحافظه القلبوبيه موسم 2020/ 2021 حيث الضم الابن الاتي: 
1- الاسراع بتتميه الريف للحد من الفارق بينه وبين الحضر وفقا للخطه التي قدمتها الحكومه بتوجيه صانع القرار السياسي لمعالجه كافه المشاكل والسلبيات الموجوده بكل قرى مصر حيث تطابقت رؤيه ونتائج البحث مع رؤيه القياده السياسيه فى اهميه الاسراع بالنهوض بالريف بنسبه أراء بلغت نحو 18.8\% بالمركز الاول وحوالي 15.6\% بالمركز الثاني من اجمالي المبحوثين

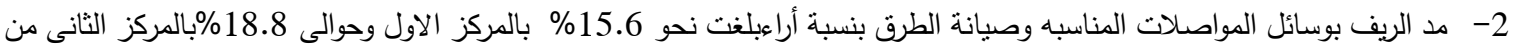
اجمالى أراء المبحوثين وهذا ما تقوم به الحكومه خلال هذه الفتره .

جدول رقم 8. التكرار النسبى لأهم المشاكل الخاصة بسكان الريف انفسهم والتى تحد من تأدية المرأة الريفية لدورها فى النتمية المستدامة بمراكز

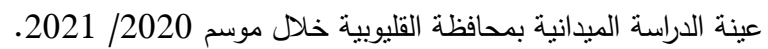

\begin{tabular}{|c|c|c|c|c|c|}
\hline \multicolumn{2}{|c|}{ 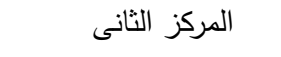 } & \multicolumn{2}{|c|}{ 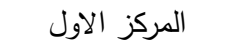 } & \multirow{2}{*}{ 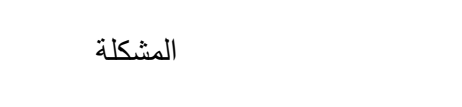 } & \multirow{2}{*}{ s } \\
\hline$\%$ & عدد & $\%$ & 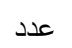 & & \\
\hline 14 & 25 & 11.2 & 20 & ارتفاع نسبة الأمية بين الأناث & 1 \\
\hline 11.2 & 20 & 11.2 & 20 & انخفاض الوعى الصحى & 2 \\
\hline 14 & 25 & 16.8 & 30 & انخفاض الوعى الغذاسى & 3 \\
\hline 5.6 & 10 & 5.6 & 10 & الاهنمام بتعليم الذكور فقط & 4 \\
\hline 11.2 & 20 & 11.2 & 20 & انخفاض الوعى البيئى & 5 \\
\hline 8.4 & 15 & 8.90 & 16 & ارتفاع نسبة كثافة السكان بالمنطقة & 6 \\
\hline 8.4 & 15 & 8.90 & 16 & انخفاض دخل الأسرة & 7 \\
\hline 14 & 25 & 11.2 & 20 & ارتفاع نسبة البطالة & 8 \\
\hline 14 & 25 & 15.00 & 28 & الظلم الواقع على المرأة فى توزيع الميراث & 9 \\
\hline 100 & 180 & 100 & 180 & الاجمالى & \\
\hline
\end{tabular}

3- مد الريف بالمياه النقيه و شبكه الكهرباء حيث أثنار بذلك نسبة حوالي 15.6\% وبنفس النسبه بالمركزين كلاعلى حده وهذا ما يتم عمله

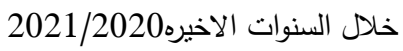
4- التوسع في انشاء المدارس لتقليل كثافه الفصول بنسبه اراء تمنل نحو 18.8\% بالمركز الاول و نحو 15.6\% بالمركز الثاني وهذا ايضا ما تسعى اليه الحكومه في السنوات الاخيره لحل هذه المشكلهمن جال برنامح تطوير التعليم .

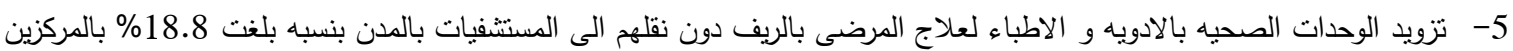

$$
\text { بنفس النسبه كلا على حده . }
$$

6- التوسع في عدد الاسواق القريبه وتحصيل الرسوم من التجار لصيانتها والمحافظه عليها وقد بلغت نسبه اراء المقرين بذلك نحو 12.4\%

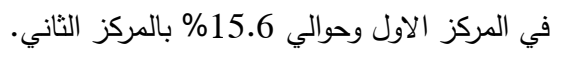

وقد لاحظ ان كافه الاساليب والمطالب التي اقر بأهميتها المبحوثين للتغلب على المشاكل التى تعمل الحكومه خلال السنوات الاخيره بتوجيه من القياده السياسيه بوضعها على ارض الواقع للتنفيذ وهذا دليل على تطابق نتائج هذه الدراسه التي يتم اجراؤها بالريف مع ما توصلت اليه الحكومه

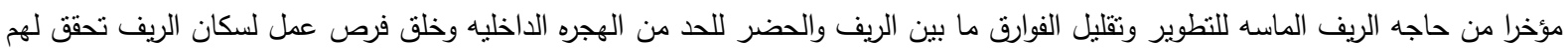
حياه كريمه هم واولادهم واحفادهم من بعدهم والنهوض بالمراه الريفيه والفتيات واعدادهم لسوق العمل كما قررتها استراتيجيه 2030.

جدول 9. التكرار النسبى لأهم الأساليب المتبعة للحد من المشاكل التى تحد من تادية المرآة الريفية لدورها فى التنمية المستدامة بمراكز عينة الدراسة الميدانية بمحافظة القليوبية خلال عام 2020/ 2021.

\begin{tabular}{|c|c|c|c|c|c|}
\hline \multicolumn{2}{|c|}{ المركز الثانى } & \multicolumn{2}{|c|}{ المركز الاول } & \multirow[t]{2}{*}{ الوسيلة المتبعة } & \multirow[t]{2}{*}{ 5 } \\
\hline$\%$ & عدد & $\%$ & عدد & & \\
\hline
\end{tabular}




\begin{tabular}{|c|c|c|c|c|c|}
\hline 15.6 & 25 & 18.8 & 30 & الاسراع بتتمية الريف للحد ما بينه وبين الحضر & 1 \\
\hline 18.6 & 30 & 15.6 & 25 & مد الريف بوسائل المواصلات وصيانة الطرق & 2 \\
\hline 15.6 & 25 & 15.6 & 25 & مد الريف بالمياه النقية وشبكة الكهرباء & 3 \\
\hline 15.6 & 25 & 18.8 & 30 & التوسع فى انشاء المدارس لتقليل كثافة الفصول & 4 \\
\hline 18.8 & 30 & 18.8 & 30 & تزويد الوحدات الصحية بالادوية والاطباء & 5 \\
\hline 15.6 & 25 & 12.4 & 20 & والمحافظة عليها. & 6 \\
\hline 100 & 160 & 100 & 160 & 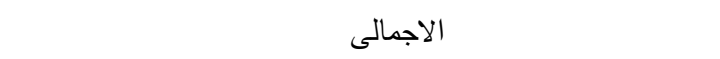 & \\
\hline
\end{tabular}

المصدر : جمعت وحسبت من بيانات الدراسة الميدانية بمراكز محافظة القليوبية خلال يناير - مارس 2021 .

تهدف استراتيجيه التتميه المستدامه رؤية مصر 2030 الى تحسين مستوى معيشه السكان الريفيين وخفض معدلات الفقر و تضييق الفجوه بين الجنسين وتتميه الموارد البشريه و توفير فرص عمل منتجه في الزراعه والانشطه المرتبطه بها وتفعيل دور المراه في مختلف الانشطه الريفيه وتحقيق

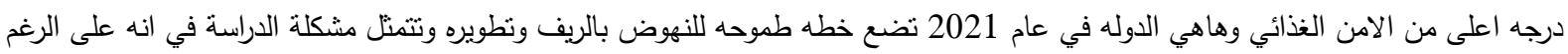
من اهتمام الدولة المتزايد خلال السنوات الاخيره لدمج المراه في المجتمع من خلال مشاركتها مشاركه جاده في التتميه المستدامه باصدار القوانين والقراراتالمدعمه سواء سواء على مستوى مصر بوجه عام او الريف بوجه خاص وما زالت تسبطر على بعض المجتمعات في الريف المصري بوجه فئه عام و محافظه القليوبيه بوجه خاص بعض العادات والتقاليد والتي نتج عنها ارتفاع نسبه الاميه بين النساء وانعكاسه سلبيا على تربيه ابنائهن وعلى لئى

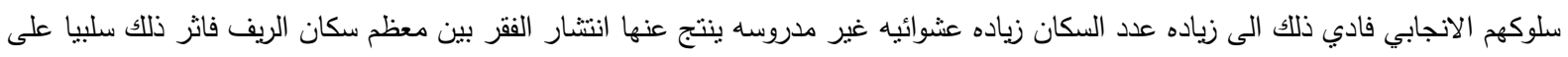
مقومات التتميه الزراعيه والاقتصاديه بالريف المصري كله ومما زاد من الاثار السلبيه لمشاركة المراه في التتميه المستدامه .خاصه خلال السنوات الماضيه بشكل ملموس في المناصب القياديه وعدم تسجيل انشطتها التي تؤديها في المنزل والحقل علاوه عن الظلم الكبير الواقع عليها سواء في لقي التعليم او الميراث الثرعي او تقييم عملها مما يؤثر سلبيا على تحفيزها في المشاركه الفعاله في التنميه المستدامه الامر الذي يتطلب اهميه التعرف

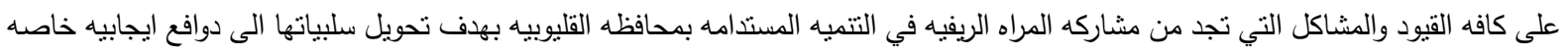
وهي تمثل نحو 48.42\% من سكان المحافظه وتهدف الدراسه بشكل اساسي الى التعرف على دور المراه الريفيه في التتميه الزراعيه والاقتصاديه المستدامه بريف محافظه القليوبيه واهم العوامل المؤثره عليها سلبيا ومن خلال معموعه من الاهداف ستسعى الدراسه لابرازها خلال مراحلها المختلفه وتستخدم الدراسه في تحقيق الهدف منها اسلوبى التحليل الوصفي والكمى المناسبين للبيانات التي يتم الحصول عليها من مجتمع الدراسه للحصول

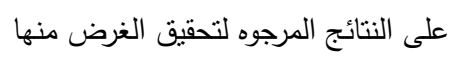
وقداعتمد الدراسه على نوعين من البيانات حيث تتمنت الاولى منها بيانات ثانويه منشوره وغير منشوره من مديريه الزراعه بالقليوبيه ومركز المعلومات بالمحافظه والجهاز المركزي للتعبئه العامه والاحصاء ومجلس المراه بالاضافه الى الدراسات وثثيه الصله بموضوع البهان البحث

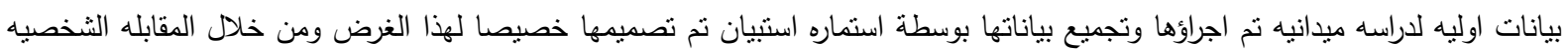
للمبحوثين وعددهم (80 اسره) من سكان الريف بمحافظه القليوبية - - متوصلت الاراسه للنتائج الآتيه : 1- تشير نتائج الدراسه الى ان حوالي 43\% فقط من سكان محافظه القليوبيه يقطن بالحضر بينما يعيش حوالى 57\% يالئه : بالريف مما يؤكد ألى أهمية تطوير الريف ومده بكافة الخدمات. 2- يتزايد عدد سكان محافظه القليوبيه بزياده سنويه تقدر بحوالي 133 الف نسمه تمثل حوالي 2.63\% من منوسط عدد السكان خلال الفتره 2008 - 2019 والبالغ نحو 5.04 مليون نسمه مما يشير الى اهميه تتظيم الاسره وتوفير الغذاء ومتطلبات الاعداد المتزايده من السكان

سنويا.

3- تتير نتائج الدراسه الميدانيه الى ان عدد من هم على قيد الحياه من الذكورالازواج والقائمين بالانفاق على اسرهم بعد استبعاد المتوفين والمطلقين بلغ حوالي 28 رجل بالمركز الاول والثاني بنفس العدد و انهم يعملون عمل رئيسي يحصلون منه على حوالي 1000 جنيه شهريا بالمركز الاول و حوالي 1500 جنيه في المركز الثاني ويتمنل هذا العمل في النشاط الزراعي بينما يعملون اعمال اضافيه اخرى سواء العمل لدي لدي الغير او في اعمال خاصه صناعيه او تجاريه كعمل ثانوي يحصلون منه على اجرا اضافياخر يقدر بحوالي 1500 جنيه بالمركزالاول و 
حوالي 1200 جنيه بالمركز الثاني شهريا يضاف للاجل الرئيسي ليبلغ اجمالي الدخل في المركز الاول حوالي 2500 شهريا بينما يقدر بنحو 2700 جنيه شهريا بالمركز الثاني للفرد الواحد.

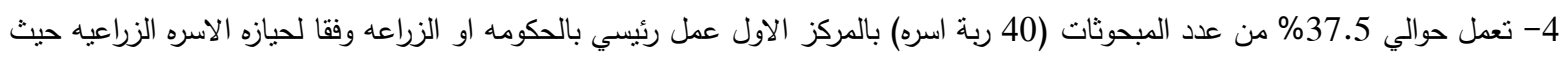

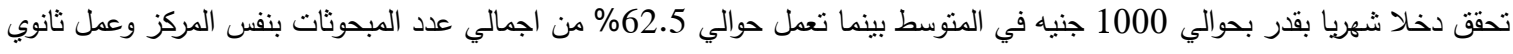

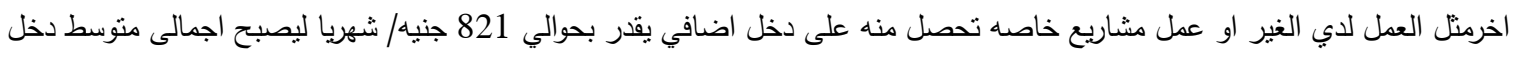

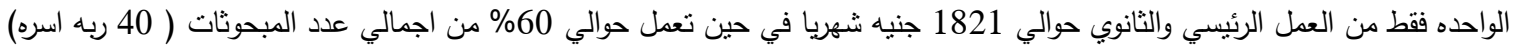

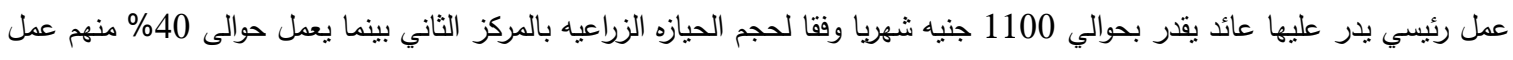

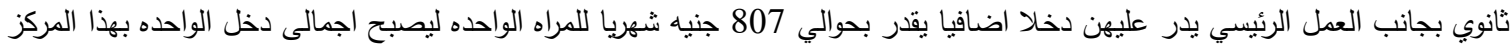

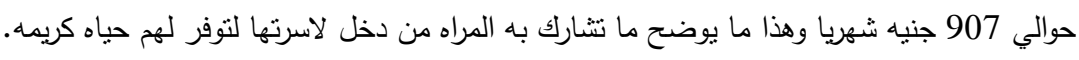

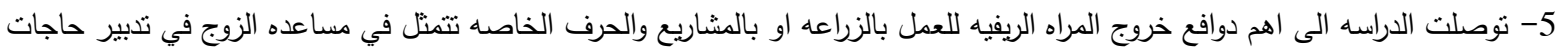

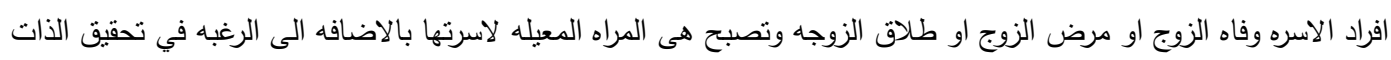

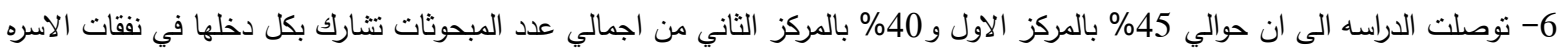

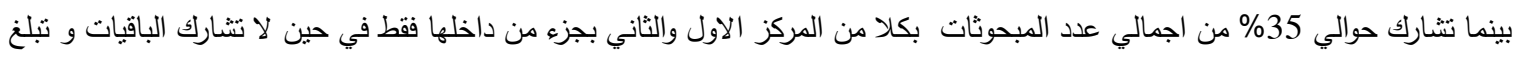

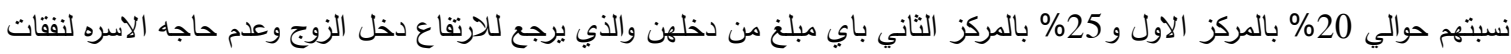
اضافيه من عملها. 7- توصلت الدراسه الى ان صافي العائد الذي يمكن ان تحققه المراه الريفيه من ممارستها للانثطه المختلفه في حاله ممارستها العمل بالمشاريع

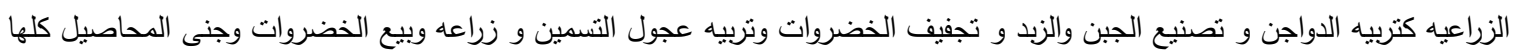

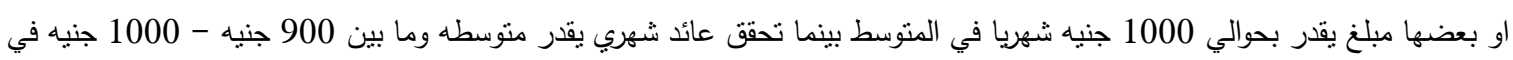

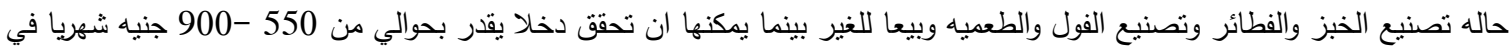
المتوسط للمراه الواحده في حاله العمل بالمشاريع والحرف الغير زراعيه ويتوقف الدخل على مساحة الحيازه الزرعيه ونوع المشروع او الحرفه

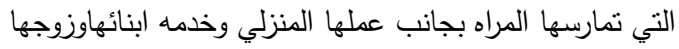

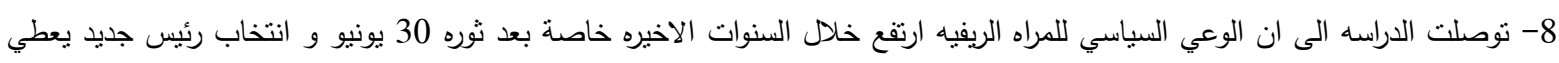

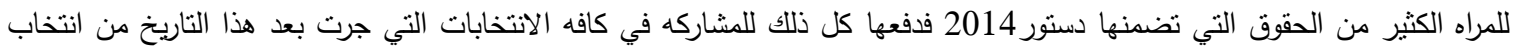

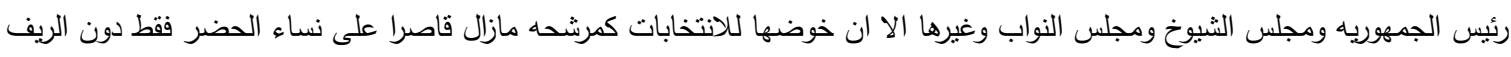
لارتفاع نسبه المتعلمات بالحضر مقارنه بالريف و تكاليف الدعايه الانتخابيه

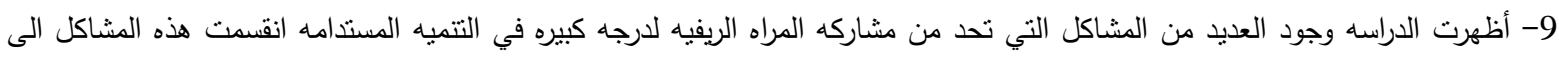

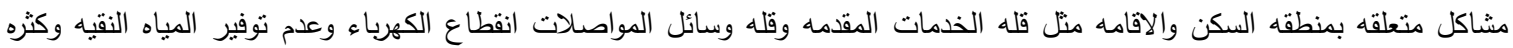

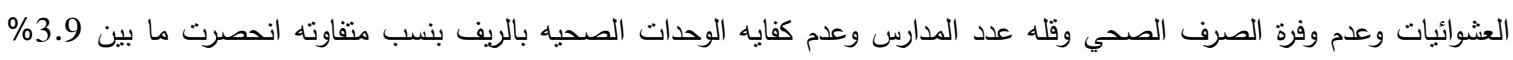

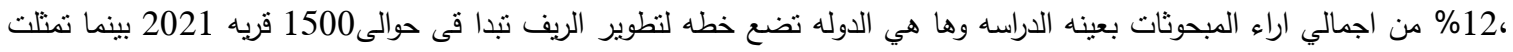

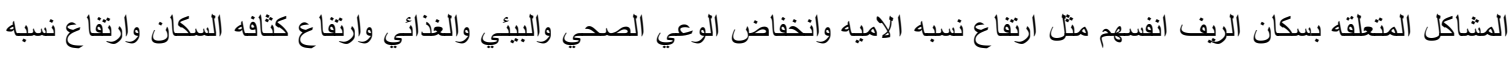

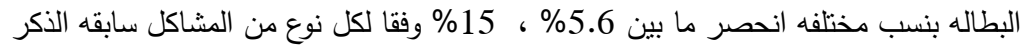

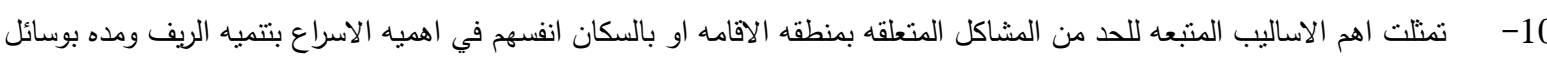

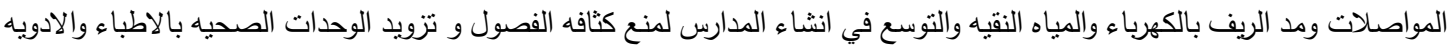
والتوسع في عدد الاسواق لتوفير منطلبات الريف من غذاء وكساء وعلاج وترفيه باسعار مناسبه

1- الاسراع بتتميه الريف ومده بالخدمات التي تقلص الفارق بين الريف والحضر لخلق فرص العمل المناسبه و توفير كافه المنطلبات المعيشيه الكريمه للسكان خاصه وان المرحله الاولى للنطوير تبدا فى 1500 قريه بتكلفه تبلغ 18 مليار جنيه عام 2021 التبن 2- توفير الرعايه الصحيه للمراه واصلاح حاله المستشفيات وكافه المنظومه الصحيه بها لهان 
3- تذليل كافه القيود على الاقتراض من البنوك المختلفه خاصه البنوك الزراعيه المنتشره بالريف لمساعده المراه المعيله على انشاء المشاريع

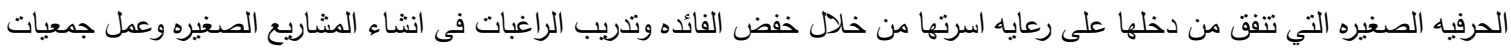

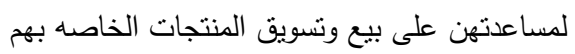

4- زياده عدد الدورات والحلقات التثقيفه والندوات التي ترفع من وعي الريفيات وتعريفهم بحقوقهم السياسيه والاقتصاديه وخلق كوادر نسائيه تعمل

في هذا المجال لاعداد الفتيات لسوق العمل

5-عمل محاكم خاصه بالميراث الثرعى للنساء لرفع الظلم عنهم في حاله حرمانهم من الميراث الثرعي المنتشر بالريف المصري ومحافظات

الصعيد

المراجع :- (20)

1- الجهاز المركزى للتعبئة العامة والاحصاء، الكتاب الاحصائى السنوى، أعداد مختلفة.

2- السيد خاطر (دكتور) مساهمة المرأه فى التتمه البشريه المؤتمر الحادى عشرللاقتصاديين الزراعيين -24-25

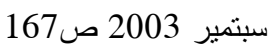

3

3- سمير عطيه محمد عرام (دكتور) امال محمد المغازي (دكتور)، دراسه اقتصاديه لنتبيه الاجاج المنزلي بريف

محافظه الثرقيه، المجله المصريه للعلوم التطبيقيه، جامعه الزقازيق، مجلد 19 عدد 5 مايو 2004

4- سمير عطيه محمد عرام (دكتور) ، أمال محمد المغازى (دكتور ) دور المرأة الريفية فيى التنمية المستدامة دراسة

حالة بمحافظة الثرقية ، المجلة المصرية للاقتصاد الزراعى، مجلد (17) العدد الثالث ، سبتمبر مكير

.2007

5- عاليه محمود حافظ (دكتور ):دور المأه الريفيه فى التتميه الريفيه بمحافظة أسيوط ,المجلة المصرية للاقتصاد

الزراعى، مجلد (12) العدد الاول ، مارس 2002 صبود

.2007،

6- مصطفى عبد الفتاح الطمبداوى (دكتور ) واخرون دور المراه الريفيه فى

التتميه المقامه بريف محافظة الشرقيه بحث مقدم الى معهد بحوث الاقتصاد - غير منشور ، مركز المعلومات

بالمحافظة ، بيانات غير منشورة.

The role of rural women in sustainable agricultural and economic development

In qalyubia governorate

1- Prof. Dr. Samir Atiya M. Aram 2- Dr. Ibrahim M. Abdulaziz Al-Hefny

Full-time Head of Research

Research

3 - Dr. Fuad Muhammad Hafez Makki

Senior Researcher 


\section{Agricultural Economics Research Institute - Agricultural Research Center \\ Corresponding author: Alhfny7500@gmail.com}

\section{Sammary}

In recent years, they have increased the state's interest in rural women and dependent women and provide the aid and loans they need to facilitate their lives.. In agriculture and its related activities, activating the role of women in various rural activities and achieving a higher degree of food security, the state in 2021 sets an ambitious plan for the advancement and development of the countryside,

The study aims mainly to identify the role of rural women in a film in sustainable agricultural and economic development in the countryside of the Qalyubia Governorate and the most important factors affecting them negatively. Identifying the most important motives for rural women to work internal or external working fluids. Indicators of economic performance efficiency are not the most important activities that the respondent performs in the study sample. Problems that limit women's participation in sustainable development in Al Ain centers and villages The most important factors that limit the problems of women not participating in sustainable development in the study sample

The study found the most important motives for rural women leaving to work in agriculture or in projects and special trades represented in helping the husband in managing the needs of family members, the death of the husband, the husband's illness, or the wife's divorce, and this woman The study revealed that there are many problems that rural women like to participate in to a large degree in sustainable development. These problems were divided into problems related to the area of residence and residence, such as the lack of services provided, the lack of transportation means, electricity shortages, lack of provision of clean water, the abundance of slums, the lack of sanitation, the small number of schools and the lack of The sufficiency of health units in the countryside, with varying rates, among those who received between $3.9 \%$ and $12 \%$ of the total opinions of the respondents in the sample of the study, and here the country is developing a plan for developing the countryside starting 1500 villages 2021, while the problems related to the rural population themselves are represented by the high rate of illiteracy

The study recommends the following Accelerating the development of the countryside and extending it with services that reduce the difference between rural and urban areas to create suitable job opportunities and provide all decent living requirements for a private population. The first stage of development begins with 1,500 villages at a cost of more than 18 billion pounds in 2021 .

Establishing special courts for the legal inheritance of women to eliminate injustice in the event that they are deprived of the legal inheritance spread in the Egyptian countryside and the governorates of Upper Egypt 